\title{
RETENTION OF PROVISIONAL CROWNS CEMENTED WITH EIGHT TEMPORARY CEMENTS. COMPARATIVE STUDY
}

\author{
RETENÇÃO DE COROAS PROVISÓRIAS CIMENTADAS COM \\ OITO CIMENTOS TEMPORÁRIOS. ESTUDO COMPARATIVO
}

\author{
Mariana Ribeiro de Moraes REGO ${ }^{1}$, Luiz Carlos SANTIAGO²
}

1- Post-graduation student, Department of Prosthodontics - Bauru Dental School.

2- Professor Assistant, Department of Prosthodontics and Dental Materials - Federal University of Rio de Janeiro.

Corresponding address: Prof. Dr. Luiz Carlos Santiago - Universidade Federal do Rio de Janeiro - Faculdade de Odontologia - Departamento de Prótese e Materiais Dentários - Av. Brigadeiro Trompowski s/n - Cidade Universitária - Ilha do Fundão - 21941-590 Rio de Janeiro - RJ. Telefone: 2125622022 - e-mail: profsantiago@aol.com

Received: November 11, 2003 - Returned for modification: January 12, 2004 - Accepted: April 15, 2004

\begin{abstract}
$M$

any temporary cements are commercially available; therefore, it is necessary to indicate them for each clinical requirement with regard to the tensile strength of prosthetic retainers. Thus, the purpose of this study was to compare the retention of provisional crowns cemented with eight temporary cements, over full crown preparations with standardized mechanical principles as height, taper, and length. For that purpose, eighty human first premolars received full crown preparation with standardized height and taper. Provisional crowns were fabricated and luted with eight brands of temporary cements. Twenty four hours after cementation, the restorations were submitted to tensile strength test in a universal testing machine and the data submitted to ANOVA and Bonferroni tests. Mean tensile strength values ranged from $20.1 \mathrm{~N}$ for Nogenol cement to $67.5 \mathrm{~N}$ for Hydro C cement. Statistically significant difference $(\mathrm{p}<0.05)$ was found between Hydro $\mathrm{C}$ and the other groups, except for Temp Bond and Rely X Temp, which presented statistically significant difference when compared to Freegenol and Nogenol temporary cements. The crowns cemented with Hydro $\mathrm{C}$ cement were more retentive that than those cemented with the other cements, except for Rely X Temp and Temp Bond. The less retentive crowns were those cemented with Nogenol and Freegenol temporary cements.
\end{abstract}

Uniterms: Temporary cements; Tensile strength; Tooth crown preparation.

\section{RESUMO}

$M$

uitas marcas de cimentos temporários estão disponíveis no mercado odontológico, sendo necessário adequá-los a cada necessidade clínica no que diz respeito à resistência à remoção dos retentores protéticos. Assim, o objetivo desse estudo foi avaliar a retenção de coroas provisórias cimentadas com oito cimentos temporários sobre preparos para coroa total com princípios mecânicos padrozinados como altura, conicidade e extensão. Para isso, oitenta primeiros pré-molares humanos receberam preparos para coroa total com altura e conicidade padronizadas. Coroas provisórias foram confeccionadas e cimentadas com oito marcas de cimentos temporários. Vinte e quatro horas após a cimentação, as restaurações foram tracionadas em uma máquina universal de ensaios e os dados submetidos aos testes estatísticos de ANOVA e Bonferroni. Os valores médios de resistência à tração variaram de 20,1 para o Nogenol a 67,5 para o Hydro C. Diferença estatisticamente significante $(p<0.05)$ foi encontrada entre o cimento Hydro C e os outros grupos, com exceção do Rely X Temp e do Temp Bond, que apresentaram diferença estatisticamente significante quando comparados aos cimentos Freegenol e Nogenol. As coroas cimentadas com Hydro $\mathrm{C}$ foram mais retentivas do que aquelas cimentadas com os outros cimentos com exceção do Rely $\mathrm{X}$ Temp e do Temp Bond. As coroas menos retentivas foram aquelas cimentadas com os cimentos Nogenol e Freegenol. Unitermos: Cimentos temporários; Resistência à tração; Coroa total, preparo. 


\section{INTRODUCTION}

A satisfactory temporary restoration must protect the pulp from external stimuli; maintain the position of teeth; maintain correct occlusion, and should be constructed so as to allow easy cleaning by the patient ${ }^{2}$. Yet, they may just meet these primordial requirements if kept stable in the mouth during the required period for fabrication of the final restoration, with no dislodgment, what could cause damage to the restoration and patient such as pulpal and periodontal alterations, modifications in tooth positioning, cavities and social constraint. For that, an adequate temporary cement must be used, to act as an interim cementing media for those provisional restorations. Moreover, provisional cementation of permanent restorations is widely practiced for a variety of clinical reasons, including the desire to make further occlusal adjustments, continuation of periodontal therapy, and inspection of abutment teeth for support. Additionally, the patient's speech, ability to maintain oral hygiene, and satisfaction with the esthetic appearance of the restoration can be evaluated ${ }^{9}$.

Temporary cements are also used in Implantology. It is known that cemented crowns have many advantages over screwed crowns, except for the irreversibility, bringing about difficulties in prosthesis removal for any adjustment or hygiene checking. ${ }^{7,10}$ To overcome this problem, temporary cements have been used for definitive cementation of implant-retained prostheses, associating the advantages of this kind of prosthesis such as esthetics and passive fit with the reversibility of cementation. In these cases, a temporary cement with low tensile strength would be indicated ${ }^{7}$.

The degree of retention of a prosthetic work is directly related to the retainer's height, taper, length and arrangement, ${ }^{3}$ and failures are usually due to improper preparation form, improper restoration fit or occlusal interference during excursive movements ${ }^{5}$. However, the choice of a proper temporary cement is also important with regard to the retention of the restorations. When the correct temporary cement is not selected, complications as microleakage, subsequent cavities and loss of the provisional restoration with consequent migration of antagonist and adjacent teeth may occur ${ }^{12}$. The properties of temporary cements vary as to flow, setting time, film thickness, retention ${ }^{8}$ and temperature ${ }^{6}$. The temporary cement should set quickly and provide enough retention for the provisional restoration to be properly maintained during function ${ }^{8}$. Thus, the retentive requirements for a temporary cement are the following: enough strength for retention of the provisional restoration, sealing of all retainers ${ }^{3-5,8,9,14}$ and easy removal of the crown when necessary, not becoming more retentive with time ${ }^{5}$.

Therefore, the purpose of this study was to compare the retention of provisional crowns cemented with eight temporary cements over full crown preparations with standardized mechanical principles: height, taper and length.

\section{MATERIALAND METHODS}

Eighty intact human first premolars, extracted for orthodontic reasons with the same average crown size were selected after achievement of informed consent from the patients. The teeth were embedded in self-curing acrylic resin in cylindrical resin bases with the aid of a surveyor, so that the teeth were kept perpendicular to the cylinder base.

For standardization of a $6^{\circ}$ taper, full crown preparations were accomplished with a diamond bur No. 4138 (KGSorensen Ind. Com. Ltda, Barueri, SP, Brazil) connected to a straight high-speed turbine coupled to a BioArt1000 surveyor (BioArt Equipamentos Odontológicos Ltda, São Carlos, SP, Brazil) with articulated rod. To standardize the surface roughness, a new diamond bur was used for each preparation.

The height of the preparations was determined in $4 \mathrm{~mm}$ with the aid of a digital pachymeter (Starret Indústria e Comércio LTDA, Itu, SP, Brazil) and a double-faced diamond disc No. 7011 (KGSorensen Ind. Com. Ltda) was used to cut the occlusal surface.

After preparation, provisional restorations of standardized thickness $(1.5 \mathrm{~mm})$ were fabricated with selfcuring acrylic resin (Duralay; Reliance Dental Mfg Co, Wort, IL) directly over the preparations with a brush ${ }^{4}$, keeping the occlusal surfaces flat.

For arrangement of the experimental groups, the provisional restorations were luted with eight temporary cements, namely: Group 1: Freegenol (GC Corporation, Tokyo, Japan); Group 2: Provy New (Dentsply, Petrópolis, RJ, Brazil); Group 3: Rely X Temp (3M ESPE AG Dental Products, Seefeld, Germany); Group 4: Temp-Bond NE (Kerr Corporation, Orange, CA); Group 5: Temp Bond (Kerr Corporation); Group 6: Provicol (Voco, Cuxhaven, Germany); Group 7: Nogenol (GC Corporation); Group 8: Hydro-C (Dentsply).

The cements were applied on the cervical region of the provisional restorations with the aid of a brush $\mathrm{h}^{4,10}$ and these restorations were set over the prepared teeth and kept in position under a $5-\mathrm{Kg}$ load $^{7}$ during the period determined by each manufacturer. After curing, excess cement was removed and the screws were fixed on the occlusal surfaces of the restorations. These screws acted as a device to provide additional retention to the clutch of the universal testing machine (EMIC Equipamentos e Sistemas de Ensaio LTDA, PR, Brazil), to avoid any sliding during the tensile strength tests, which were conducted at a crosshead speed of 0.5 $\mathrm{mm} / \mathrm{min}$.

To describe the results, means and standard deviations were calculated. The results obtained for the eight temporary cements were compared with an analysis of variance (ANOVA). Afterwards, the Bonferroni test was performed for multiple comparisons if the ANOVA showed a statistically significant difference. In all cases, a significance level of 5\% was adopted. 


\section{RESULTS}

The mean values for the tensile strength for each group are presented in Table 1.

The ANOVA test revealed statistically significant difference $(p<0.05)$ between groups. The Bonferroni test was used for individual comparisons and showed statistically significant difference $(\mathrm{p}<0.05)$ between Hydro$\mathrm{C}$ group and the other five groups, except for Rely X Temp and Temp Bond. Statistically significant difference was also found when Rely X Temp and Temp Bond groups were compared to Freegenol and Nogenol groups.

\section{DISCUSSION}

In this study, a great variation was found in the tensile strength values for each group. This indicates that the commercially available brands present different physical properties, which might be due to the different compositions of the eight evaluated temporary cements (zinc oxideeugenol, noneugenol containing zinc oxide, calcium hydroxide), as proposed by Olin, et al. ${ }^{9}$

In a way, it may provide the clinician with many options with regard to the retention requirements of restorations, depending on the design and extension of the prosthesis. Many times, the requirement for an increase in retention leads the clinician to increase the catalyst-to-base ratio ${ }^{7}$. However, when increasing the cement consistency, it might be difficult to keep the film thickness within the guidelines established by ANSI/ADA specification No. $30 .{ }^{13}$ Thus, it would be more adequate to choose a temporary cement that confirmedly offers the highest tensile strength.

The results of this study are in accordance with the findings of Akashi, et al. ${ }^{1}$, on which the Dycal temporary cement (which has the same composition of Hydro-C)

TABLE 1- Mean values (in Newtons) for tensile strength and standard deviations for each group

\begin{tabular}{ll|l}
\hline $\begin{array}{l}\text { Temporary } \\
\text { Cement }\end{array}$ & $\begin{array}{l}\text { Tensile } \\
\text { Strength }\end{array}$ & $\begin{array}{l}\text { Standard } \\
\text { Deviation }\end{array}$ \\
\hline Nogenol & 20.1 & 7.33 \\
Freegenol & 31.0 & 11.68 \\
Temp Bond NE & 33.8 \\
Provicol & 36.3 & 12.50 \\
Provy New & 42.4 & 12.58 \\
Rely X Temp & 50.6 & 10.73 \\
Temp Bond & 53.5 & 12.72 \\
Hydro C & 67.5 & 13.50 \\
\hline
\end{tabular}

Groups connected with vertical lines are not significantly different $(p>0.05)$ showed higher retentive values, with no statistical difference, when compared to Temp Bond, yet with statistically significant difference $(\mathrm{p}<0.05)$ when compared to Temp Bond NE. They are also in agreement with the findings of Millstein, et al. ${ }^{8}$, on which Temp Bond showed significant higher retentive values then Freegenol.

Yet, for Lepe, et al. ${ }^{5}$, Temp Bond NE showed similar retentive results when compared to a calcium hydroxide cement, and both presented higher retentive results when compared to Temp Bond temporary cement. Olin, et al. ${ }^{9}$ also found different results. They showed that Nogenol and Freegenol presented higher retentive values than Temp Bond.

Ishikiriama, et al. ${ }^{4}$ found higher retentive values for the calcium hydroxide temporary cement (Dycal), but very low results for Temp Bond.

A limitation of this in vitro study is the lack of temperature variation, which is found in the oral environment, once the temperature of the mouth and of the ingested food might interfere with the physical properties of the temporary cements as shown by Mesu ${ }^{10}$ Silvey and Myers ${ }^{14}$, accomplished an in vivo study that included the oral environment temperature variation, yet the cement failure evaluation was restricted to the moment when the patient noticed dislodgement. Moreover, in a study like that, standardization of the preparations and cementation is not possible.

Further studies should be conducted to evaluate (1) the influence of the composition on the tensile strength of temporary cements, since some substances such as eugenol present clinical implications such as alterations in the curing of acrylic or composite resins and allergic reactions; (2) the influence of temperature on the tensile strength of these cements; and (3) non-destructive fatigue tests.

\section{CONCLUSION}

Within the limitations of this study, it can be concluded that crowns cemented with Hydro-C cement had the best results when compared to those cemented with the other temporary cements, except for Rely X Temp and Temp Bond, and that crowns cemented with these two cements were better than those cemented with Freegenol and Nogenol cements with regard to the tensile strength.

\section{REFERENCES}

1- Akashi AE, Francischone CE, Tokutsune E, Silva Jr W. Effect of different types of temporary cements on the tensile strength and marginal adaptation of crowns on implants. J Adhes Dent 2002; 4:309-15.

2- Fisher DW, Shillingburg HT, Dewhirst RB. Indirect temporary restorations. J Am Dent Assoc 1971; 82:160-3.

3- Gilson TD, Myers GE. Clinical studies of dental cements: III. Seven zinc oxide-eugenol cements used for temporarily cementing completed restorations. J Dent Res 1975; 20:361-7. 
4- Ishikiriama A, Busato ALS, Navarro MFL, Mondelli J. Temporary cementation of acrylic resin and cast complete crowns. J Prosthet Dent 1984; 51:637-41.

5- Lepe X, Bales DJ, Johnson GH. Retention of provisional crowns fabricated from two materials with the use of four temporary cements. J Prosthet Dent 1999; 81:469-75.

6- Mesu FP. The effect of temperature on the compressive and tensile strengths of cements. J Prosthet Dent 1990; 21:197-200.

7- Michalakis KX, Pissiotis AL, Hirayama H. Cement failure loads of 4 provisional luting agents used for the cementation of implantsupported fixed partial dentures. Int J Oral Maxillofac Implants 2000, $15: 545-9$

8- Millstein PL, Hazan E, Nathanson D. Effect of aging on temporary cement retention in vitro. J Prosthet Dent 1991; 65:768-71.

9- Olin OS, Rudney JD, Hill EM. Retentive strength of six temporary dental cements. Quintessence Int 1983; 49:59-62.

10- Ramp MH, Dixon DL, Ramp LC, Breeding LC, Barber LL. Tensile bond strengths of provisional luting agents used with an implant system. J Prosthet Dent 1999; 81:510-4.

11- Revised American National Standard / American Dental Association Specification No.30 for Dental Oxide Eugenol Cements and Zinc Oxide Non-Eugenol Cements. Approved March 6, 1990. Effective March 6, 1991.

12- Sadan A. Clinical considerations in cement selection for provisional restorations - Part 1. Pract Period Aest Dent 2000; 12:638.

13- Silvey RG, Myers GE. Clinical study of dental cements. VII. A study of bridge retainers luted with three different dental cements. J Dent Res 1978; 57:703-7.

14- Stevens L. The properties of four dental cements. Aust Dent J $1975 ; 20: 361-7$ 